\title{
Inhibition of Transformation by Antibodies against Competent Haemophilus influenzae
}

\author{
By D. P. BINGHAM* AND B. J. BARNHART \\ Biomedical Research Group, Los Alamos Scientific Laboratory, \\ University of California, Los Alamos, New Mexico, 87544, U.S.A.
}

(Received 24 July 1972; revised 21 November 1972)

\begin{abstract}
SUMMARY
Antibodies prepared against competent and non-competent Haemophilus influenzae were compared as to their effect on DNA binding and transformation. The gamma globulin fraction of rabbit antisera prepared against competent bacteria inhibited irreversible binding of DNA and transformation to $21 \%$ and $7 \%$, respectively, of the control values. Antibodies against non-competent bacteria had an insignificant effect on irreversible binding or transformation. The transforming ability of DNA was not altered by exposure to competent organism antibodies. The antibody activity was reduced to one-third of the control value by heating for $\mathrm{IO} \mathrm{min}$ in a boiling water bath. Bacterial agglutinating ability of the antibodies was completely removed by papain treatment, while only $10 \%$ of the antitransforming activity was destroyed. The kinetics and dose-response of antibodies on inhibition of irreversible uptake and transformation are reported. It was concluded that antigenic determinants related to irreversible binding and at least one additional step in the uptake of transforming DNA are integral components of the competent state of $H$. influenzae.
\end{abstract}

\section{INTRODUCTION}

Bacterial transformation is defined as the process by which a population of bacteria acquires new genetic information from variant strains as a result of cellular uptake and integration of extracellular DNA. A bacterial cell is termed 'competent' if it is able to take up DNA irreversibly and subsequently undergo transformation (Goodgal \& Herriott, 196I). The irreversible binding step occurs apparently by a highly organized energydependent system (Fox \& Hotchkiss, 1957; Barnhart \& Herriott, 1963; Stuy \& Stern, 1964). While the competent state versus the non-competent state is poorly understood, it is generally true that physiologically non-competent bacteria are unable to bind DNA irreversibly (Spizizen, Reilly \& Evans, 1966). The requirement for protein synthesis during competence development suggests that a receptor protein may be involved in DNA uptake (Stuy, 1962). Antisera from rabbits injected with competent pneumococci, streptococci, and Neisseria catarrhalis contained antibodies which inhibited transformation (Nova, Gallis \& Beiser, 1963; Pakula, 1965; Tomasz \& Beiser, 1965; Snyder \& Otero, 197c). Similar antisera against non-competent bacteria were not inhibitory to transformation. The specific inhibitory effect of the competent bacteria antisera suggested that antigenic determinants unique to organisms in the competent state are part of the mechanism involved in transformation.

* Present address: Department of Biology, Killgore Research Center, West Texas State University, Canyon, Texas, 79015, U.S.A.

Vol. 75, No. I, was issued 22 March 1973 
The present experimental results support the hypothesis that specific components of bacteria are involved in DNA uptake and extend it to include the Haemophilus transformation system. Antibodies prepared against competent Haemophilus influenzae inhibited irreversible binding of DNA and subsequent transformation, while antibodies against noncompetent bacteria showed no specific inhibitory effect. The ability of DNA to transform was not altered by prior exposure of the nucleic acid to competent cell-antibodies. The effects of heat and papain on anti-transforming antibodies are described along with kinetics of reaction between antibody and frequency of transformation in competent bacteria.

\section{METHODS}

Organism. Haemophilus influenzae type Rd was originally isolated by Alexander \& Leidy (I953). The Rd stock used in this laboratory was originally obtained from Dr Roger M. Herriott. Stock cultures were grown in Difco heart-infusion broth (Spencer \& Herriott, 1965) supplemented with $2 \mu \mathrm{g}$ nicotinamide adenine dinucleotide (NAD)/ml and 10 $\mu \mathrm{g}$ haemin $/ \mathrm{ml}$ to an extinction of $\mathrm{I} \cdot 0$ measured as $650 \mathrm{~nm}$ on a Spectronic 20 spectrophotometer $\left(2 \times 10^{9}\right.$ viable centres $\left./ \mathrm{ml}\right)$ and stored in growth medium plus glycerol $(\mathrm{I} 7.5 \%, \mathrm{v} / \mathrm{v})$ at $-86^{\circ} \mathrm{C}$.

Preparation of competent and non-competent bacteria. The bacteria were made competent by growing in $50 \mathrm{ml}$ of heart-infusion broth followed by $3 \mathrm{~h}$ of incubation in $55 \mathrm{ml}$ of M II medium, as described by Spencer \& Herriott (1965). The same procedure was used to make non-competent bacteria except $\mathrm{L}$-valine was added to the M II medium at a final concentration of $10 \mu \mathrm{g} / \mathrm{ml}$ (Spencer \& Herriott, 1965).

Preparation of antisera. Formaldehyde $(55 \mathrm{ml}, 0.4 \%)$ and $0.85 \% \mathrm{NaCl}$ in sterile distilled water $(0.4 \%$ formalized saline) were added to both competent and non-competent cultures of Haemophilus influenzae. The formalin-treated cultures were incubated overnight at room temperature. The bacteria were centrifuged the following day and resuspended in $25 \mathrm{ml}$ of $0.1 \%$ formalized saline. The preparation was stored at $2{ }^{\circ} \mathrm{C}$ until used for injection. New Zealand White male rabbits were injected intravenously with $2.0 \mathrm{ml}$ of injection preparation $\left(\mathrm{I} \cdot 6 \times 1 \mathrm{IO}^{10}\right.$ viable centres) on Monday, Wednesday and Friday of each week until the antibody agglutination titre for $H$. influenzae reached 2560 . The rabbits were bled 6 days after the last injection by cardiac puncture, and the sera were separated and stored at $2{ }^{\circ} \mathrm{C}$. Due to the bacteriolytic activity of whole antisera, the gamma globulin fractions (antibodies) of the antisera were isolated by sodium sulphate precipitation (Kekwick, I938) and used in all experiments.

Preparation of labelled and unlabelled DNA. The ${ }^{14} \mathrm{C}$-labelled transforming DNA bearing the $\mathrm{Nb}_{1}$-marker (resistant to $2.5 \mu \mathrm{g}$ novobiocin $/ \mathrm{ml}$ ) was prepared from novobiocin-resistant Haemophilus influenzae Rd grown in $\mathrm{MI}_{\mathrm{c}}$ medium (Herriott, Meyer, Vogt \& Modan, 1970) containing $2.4 \mu \mathrm{g}$ novobiocin $/ \mathrm{ml}$ and $0.25 \mu \mathrm{Ci}\left[2^{-14} \mathrm{C}\right]$ thymidine $/ \mathrm{ml}$. The DNA was isolated according to the method of Goodgal \& Herriott (I96I) and was subsequently dialysed for $48 \mathrm{~h}$ against 250 vol. of $0.05 \mathrm{M}$-sodium citrate saline to remove low mol. wt ${ }^{14} \mathrm{C}$-labelled material (sp. act. 5000 c.p.m. $/ \mu \mathrm{g}$ DNA).

The unlabelled $\mathrm{Nb}_{1}$-DNA was prepared by growing novobiocin-resistant bacteria in brain-heart infusion broth supplemented with $2 \mu \mathrm{g} \mathrm{NAD} / \mathrm{ml}$, Io $\mu \mathrm{g}$ haemin $/ \mathrm{ml}$, and $2.4 \mu \mathrm{g}$ novobiocin $/ \mathrm{ml}$ to an extinction corresponding to $2 \times 10^{9}$ viable centres $/ \mathrm{ml}$. The DNA was isolated according to the method of Goodgal \& Herriott (I96I).

Transformation assay. Transformations were carried out by adding $0.9 \mathrm{ml}$ competent bacteria ( $\mathrm{I} \cdot 8 \times 10^{9}$ viable centres) to $0.1 \mathrm{ml} 20 \mu \mathrm{g} \mathrm{Nb} \mathrm{N}_{1}-\mathrm{DNA} / \mathrm{ml}$ and incubating for $\mathrm{I} 5 \mathrm{~min}$ at $36^{\circ} \mathrm{C}$. A portion ( $0.1 \mathrm{ml}$ of I $\mathrm{mg}$ pancreatic deoxyribonuclease $/ \mathrm{ml}$ (DNase) in $0 \cdot \mathrm{I} \mathrm{M}-\mathrm{MgCl}_{2}$ 
was added and the mixture incubated for $5 \mathrm{~min}$ before diluting and pour-plating. The overlay technique described by Goodgal \& Herriott (I96I) was used to determine the number of bacteria transformed to the $\mathrm{Nb}_{1}$-marker.

Antibody assay. When testing the antibody effect on transformation and binding of transforming DNA, $0.9 \mathrm{ml}$ of competent bacteria ( $\mathrm{I} \cdot 8 \times 10^{9}$ viable centres) was added to $0 . \mathrm{I} \mathrm{ml}$ of the desired dilution of antibody and incubated for $30 \mathrm{~min}$. After treating the competent organisms with antibody, $2 \mu \mathrm{g}{ }^{14} \mathrm{C}$-labelled $\mathrm{Nb}_{1}$-DNA were added, and the mixture was incubated for another $15 \mathrm{~min}$ followed by a 5 -min exposure to $100 \mu \mathrm{g}$ DNase. The transformation culture was then tested for irreversibly bound $\left[{ }^{14} \mathrm{C}\right] \mathrm{DNA}$ and number of $\mathrm{Nb}_{1^{-}}$ transformed bacteria. Saline was used in the controls in place of antibody. The percentage inhibition $(\% \mathrm{I})$ by antibody preparations was calculated using the equation

$$
\% \mathrm{I}=\frac{\text { Pre-immunization value }- \text { treated value }}{\text { Pre-immunization control value }} \mathrm{I} 00 .
$$

This method of testing the antibody was used in all experiments except the kinetic studies. In the kinetic experiments bacteria were exposed to antibody in the same way but for varying lengths of time, after which $0 . \mathrm{I} \mathrm{ml}$ of the bacteria plus antibody was added to $0.9 \mathrm{ml}$ of $\mathrm{M} \mathrm{II}$ medium containing $2 \mu \mathrm{g} \mathrm{Nb} \mathrm{Nb}_{1}$-DNA and Io $\mu \mathrm{g} \mathrm{L}$-valine and treated as described in the previous section (viable centres and number of transformed organisms were consequently one-tenth that of other experiments).

Assay for bound ${ }^{14} C$-labelled $N b_{1}-D N A$. After DNase treatment of the transformation culture, a sample (O.I $\mathrm{ml}$ ) of organisms was taken to test for the number of bacteria transformed to the $\mathrm{Nb}_{\mathbf{1}}$-marker. To assay for irreversibly bound DNA, the remainder of the culture was centrifuged and washed three times (more washes were unnecessary) with equal volumes of saline and resuspended after the last wash in $0.5 \mathrm{vol}$. of saline. A sample (0. I ml) was dried and counted on a paper disc using $10 \mathrm{ml}$ of toluene scintillation fluid $(32 \mathrm{~g}$ of 2.5-diphenyloxazole, $0.8 \mathrm{~g}$ of $\mathrm{I} \cdot 4$-bis-2(5-phenyloxazolyl)benzene, and 7.51 of toluene). Each sample was counted for Io min in a Packard Model 3003 Tri-Carb scintillation spectrometer. ${ }^{14} \mathrm{C}$-labelled $\mathrm{Nb}_{1}$-DNA had a specific activity of between 4700 to $5300 \mathrm{c} . \mathrm{p} . \mathrm{m} . / \mu \mathrm{g}$ DNA.

Papain treatment of antibody. Antibodies against competent Haemophilus influenzae were exposed to the action of activated papain (Porter, 1958) at $37^{\circ} \mathrm{C}$ for $\mathrm{I} 5 \mathrm{~min}$ and $\mathrm{I} 6 \mathrm{~h}$, respectively. The weight ratio of antibody protein to papain was 64: I. The papain (Worthington PAP 9KA) was activated in a buffer solution of 0.1 M-sodium phosphate, $\mathrm{pH} 7 \cdot 0$; $0.01 \mathrm{M}$-cysteine; and $0.002 \mathrm{M}$-EDTA. The effect of papain on antibodies was determined by the antibody assay described in a previous section.

\section{RESULTS}

Antisera effect on DNA binding and transformation

Antibodies prepared against competent Haemophilus influenzae Rd organisms (anti-CRd bodies) inhibited binding of transforming DNA to $21 \%$ of the control and decreased the level of transformation to novobiocin resistance to $7 \%$ (Table I). Antibodies against noncompetent bacteria (anti-NCRd bodies) had no more effect on binding of transforming DNA or on decreasing the level of transformation than the pre-immunization antibodies derived from rabbits prior to injection with non-competent organisms. Antibodies against competent and non-competent bacteria were incubated separately with transforming DNA 
Table I. Transformation and irreversible binding of $\left[{ }^{14} \mathrm{C}\right] N b_{1}-D N A$ in competent bacteria pretreated with anti-CRd bodies or anti-NCRd bodies

\begin{tabular}{|c|c|c|c|c|c|}
\hline $\begin{array}{l}\text { Pre-incubation of } \\
\text { competent bacteria } \\
\text { (I } 5 \text { min, } 0.9 \mathrm{ml} \text { ) } \\
\text { with: }\end{array}$ & $\begin{array}{l}\text { Viable centres } \\
\quad(\text { per } \mathrm{ml})\end{array}$ & $\begin{array}{c}\mathrm{Nb}_{1} \\
\text { transformations } \\
\text { (number } / \mathrm{ml} \text { ) }\end{array}$ & $\begin{array}{c}\text { Inhibition } \\
(\%)\end{array}$ & $\begin{array}{c}\text { Irreversibly- } \\
\text { bound } \\
{\left[{ }^{14} \mathrm{C}\right] \mathrm{DNA}} \\
\text { (c.p.m. } / \mathrm{ml} \text { ) }\end{array}$ & $\begin{array}{c}\text { Inhibition } \\
(\%)\end{array}$ \\
\hline Saline, $\mathrm{O} . \mathrm{I} \mathrm{ml}$ & $\mathrm{I} \cdot 28 \times 10^{9}$ & $1 \cdot 74 \times 10^{7}$ & - & 2704 & - \\
\hline Anti-NCRd bodies, $O \cdot 1 \mathrm{ml}$ & $5.30 \times 10^{8}$ & $1 \cdot 16 \times 10^{7}$ & 9 & 2352 & 7 \\
\hline Anti-CRd bodies, $0.1 \mathrm{ml}$ & $6.90 \times 10^{8}$ & $9.60 \times 10^{5}$ & 93 & 542 & 79 \\
\hline $\begin{array}{l}\text { Pre-immunization anti- } \\
\text { bodies, }{ }^{*} \text { o. I } \mathrm{ml}\end{array}$ & $1.08 \times 10^{9}$ & $1.29 \times 10^{7}$ & 0 & 2630 & 0 \\
\hline $\begin{array}{l}\text { Pre-immunization anti- } \\
\text { bodies, } \uparrow 0.1 \mathrm{ml}\end{array}$ & $1 \cdot 01 \times 10^{9}$ & $1 \cdot 27 \times 10^{?}$ & o & 2525 & o \\
\hline
\end{tabular}

Table 2. Effect of antibodies prepared against competent and non-competent Haemophilus influenzae on transforming DNA

\begin{tabular}{|c|c|c|c|}
\hline $\begin{array}{l}\text { Pretreatment of } \\
\text { transforming DNA } \\
\text { (I } 5 \mathrm{~min} \text { ) }\end{array}$ & $\begin{array}{c}\text { Viable } \\
\text { centres } \\
\left(10^{-7} / \mathrm{ml}\right)\end{array}$ & $\begin{array}{l}\mathrm{Nb}_{1} \text { trans- } \\
\text { formations* } \\
\left(10^{-5} / \mathrm{ml}\right)\end{array}$ & $\begin{array}{c}\text { Inhibition } \\
(\%)\end{array}$ \\
\hline Saline control & $1 \cdot 58$ & $1 \cdot 29$ & - \\
\hline Pre-immunization antibodies $\dagger$ & $I \cdot 43$ & $I \cdot 24$ & 0 \\
\hline Anti-NCRd bodies & $\mathbf{I} \cdot 57$ & $1 \cdot 17$ & $5 \cdot 5$ \\
\hline Anti-CRd bodies & $1 \cdot 53$ & $1 \cdot 22$ & $I \cdot 6$ \\
\hline
\end{tabular}

* The total number of transformations is lower in this table because the treated transforming DNA was diluted after treatment to $10^{-3} \mu \mathrm{g} / \mathrm{ml}$ so that it was the limiting factor and so that any loss in biological activity of the DNA could be detected.

$\dagger$ Antibody activity against competent organisms prior to injecting rabbits with competent bacteria.

to determine if inhibition of binding and transformation was due to antibody-DNA interactions. After incubation for $15 \mathrm{~min}$ with DNA, the solutions were diluted to an ineffective antiserum level ( $1: 1000$ ), and the DNA was tested for any loss in transforming activity as compared with a pre-immunization antibody-treated DNA control. The results (Table 2) showed no significant changes in transforming activity of antibody-treated DNA.

\section{Inhibition by antibodies}

The effect of various concentrations of antibodies was tested on binding of transforming DNA and transformation to novobiocin resistance in an excess of DNA. In Fig. I the dose-response curve for anti-CRd bodies is linear from the I: Io dilution to the I:200 dilution for both binding of DNA and transformation to novobiocin resistance. The slope of the DNA binding curve is half that of the transformation curve, suggesting that two molecules of antibody are required to block binding while one is sufficient to block transformation. At dilutions of $1: 1000$ and greater, the inhibitory effect of the antibodies was diluted out. This is similar to results reported by Tomasz \& Beiser (1965) for antisera made against competent pneumococci.

The titration of anti-NCRd bodies is shown in Fig. 2. Transformation to novobiocin resistance was inhibited slightly at higher concentrations of antibody. This was expected for two reasons: (i) non-competent bacteria against which the antibodies were prepared showed 


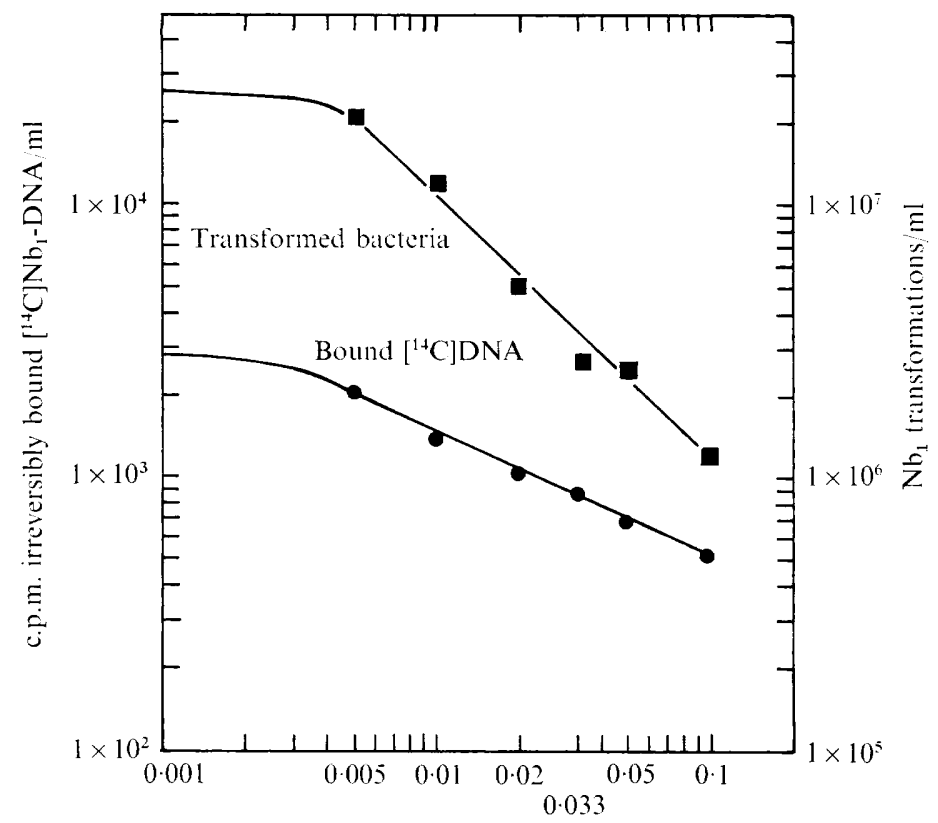

ml Anti-CRd serum/ml competent bacteria

Fig. I. Dose-response curve to anti-CRd bodies. Competent Rd bacteria were incubated for 30 min with increasing concentrations of antiserum prepared against competent $\mathrm{Rd}$ organisms. The bacteria were exposed to $\left[{ }^{14} \mathrm{C}\right] \mathrm{Nb}_{1}$-DNA for $15 \mathrm{~min}$ and assayed for c.p.m. of irreversibly bound DNA and number of novobiocin-resistant $\left(\mathrm{Nb}_{1}\right)$ transformations.

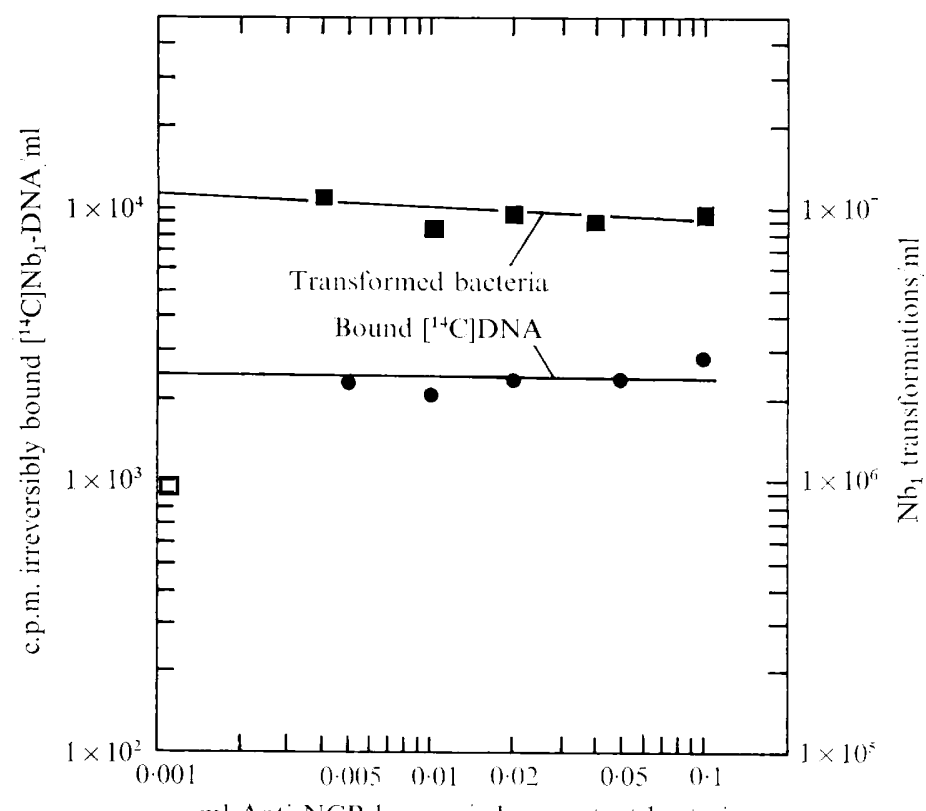

$\mathrm{ml}$ Anti-NCRd serum ml competent bacteria

Fig. 2. Dose-response curve to anti-NCRd bodies. Competent Rd bacteria were incubated for 30 min with increasing concentrations of antiserum prepared against non-competent Rd organisms. The bacteria were then exposed to $\left[{ }^{14} \mathrm{C}\right] \mathrm{Nb}_{1}$-DNA for $15 \mathrm{~min}$ and assayed for c.p.m. of irreversibly bound DNA and number of novobiocin-resistant $\left(\mathrm{Nb}_{1}\right)$ transformations. 


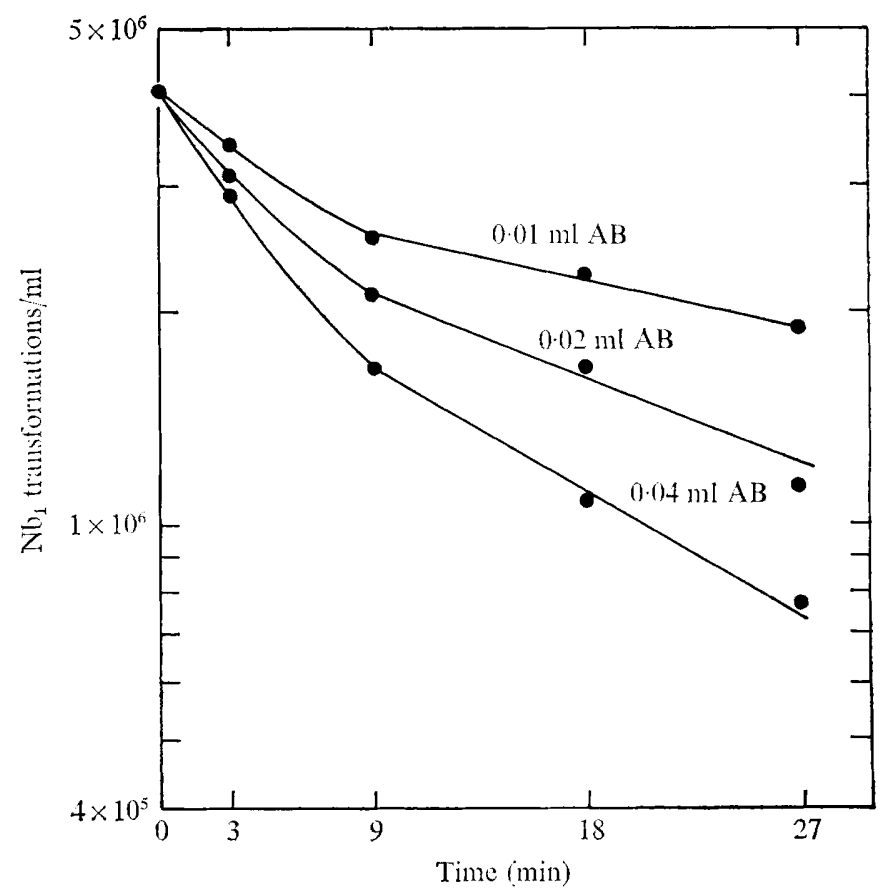

Fig. 3. Inhibition of transformation to novobiocin resistance $\left(\mathrm{Nb}_{1}\right)$ by anti-CRd bodies (AB) as a function of time. Competent bacteria were exposed to antibodies against competent $\mathrm{Rd}$ bacteria for increasing periods of time. The organisms were then exposed to $\mathrm{Nb}_{1}$-DNA for $\mathrm{I} 5 \mathrm{~min}$ and assayed for $\mathrm{Nb}_{1}$ transformations.

Table 3. Effect of heat on antibodies against competent Haemophilus influenzae

$\begin{array}{lccc}\begin{array}{c}\text { Anti-CRd } \\ \text { bodies treatment }\end{array} & \begin{array}{c}\text { Viable } \\ \text { centres } \\ \left(\mathrm{I} 0^{-8} / \mathrm{ml}\right)\end{array} & \begin{array}{c}\mathrm{Nb} \\ \text { transformations } \\ (\text { number } / \mathrm{ml})\end{array} & \begin{array}{c}\text { Inhibition } \\ (\%)\end{array} \\ \text { Control (no antibody) } & 4.50 & 1.36 \times 10^{7} & 0 \\ 28^{\circ} \mathrm{C} \text { for 30 min } & 1 \cdot 53 & 8.80 \times 10^{5} & 94 \\ 56{ }^{\circ} \mathrm{C} \text { for 30 min } & 2 \cdot 50 & 2.30 \times 10^{6} & 89 \\ 92{ }^{\circ} \mathrm{C} \text { for Io min } & 3.50 & 9.00 \times 10^{6} & 34\end{array}$

low levels of transformation; and (ii) pre-immunization antibody preparations showed slight inhibition of transformation (Table $\mathrm{I}$ ). The binding of transforming DNA was not altered by increased antibody concentration (Fig. 2).

\section{Kinetics of inhibition by antibodies}

Fig. 3 shows the action of three different dilutions of anti-CRd bodies over a $27 \mathrm{~min}$ period, during which untreated competent cells maintained the same level of transformation to novobiocin resistance. Inhibition of transformation by anti-CRd bodies is very rapid during the first 3 to $6 \mathrm{~min}$ of exposure. From between 6 and $9 \mathrm{~min}$ to $27 \mathrm{~min}$, the rate of inhibition is less but constant. Even in experiments that ran for $64 \mathrm{~min}$, the continued rate of inhibition remained constant after the first $10 \mathrm{~min}$. 
Table 4. Effect of treating anti-CRd bodies with papain prior to exposure to competent bacteria

\section{Anti-CRd body treatment}

Control (no antibodies)

Papain control ( $0.02 \mathrm{mg}$ of papain, no antibodies)

Anti-CRd body control, I $46 \mathrm{mg}$ (anti-CRd bodies, no papain)

Anti-CRd bodies, $1.46 \mathrm{mg}$, incubated with $0.02 \mathrm{mg}$ papain for $15 \mathrm{~min}$

Anti-CRd bodies, $\mathrm{I} \cdot 46 \mathrm{mg}$, incubated with $0.02 \mathrm{mg}$ papain for $16 \mathrm{~h}$

$\begin{array}{ccc}\begin{array}{c}\text { Viable } \\ \text { centres } \\ \left(\mathrm{I} 0^{-8} / \mathrm{ml}\right)\end{array} & \begin{array}{c}\mathrm{Nb}_{1} \\ \text { transformations } \\ (\text { number } / \mathrm{ml})\end{array} & \begin{array}{c}\text { Inhibition } \\ (\%)\end{array} \\ 6.00 & 4.3 \times 10^{6} & 0 \\ 6.45 & 4.5 \times 10^{6} & 0 \\ 2.85 & 5.0 \times 10^{5} & 89 \\ 4.25 & 5.2 \times 10^{5} & 88 \\ 7.10 & 9.0 \times 10^{5} & 80\end{array}$
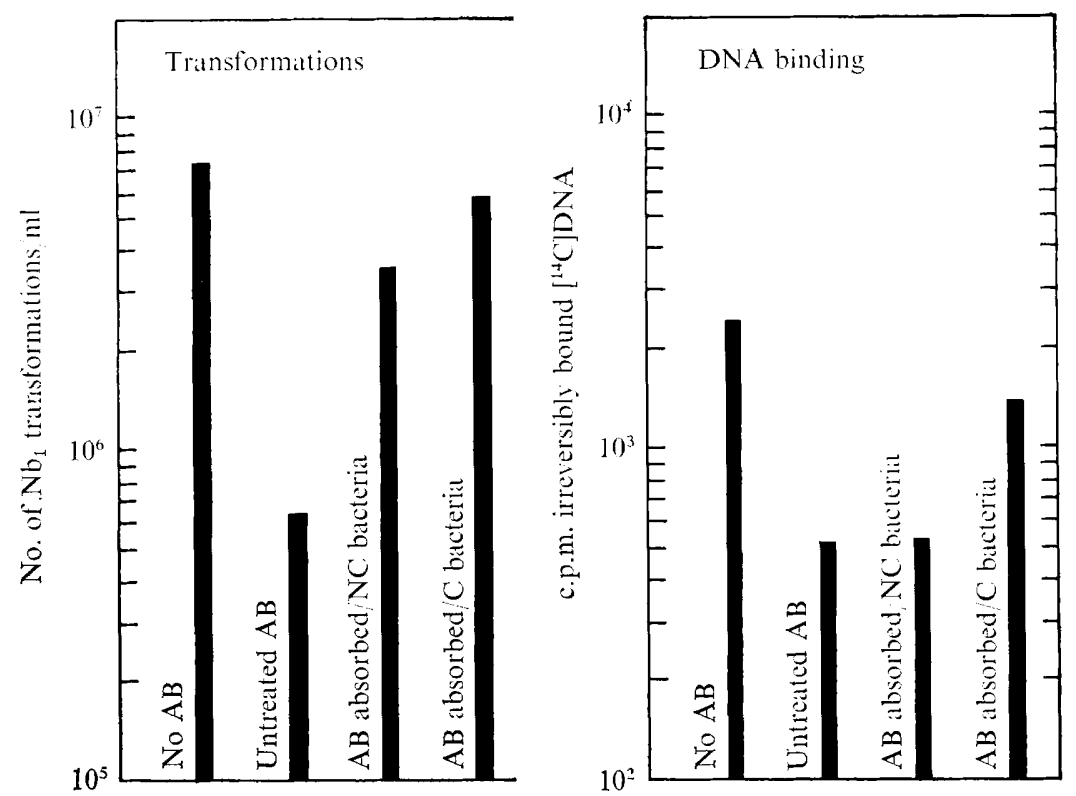

Fig. 4. Absorption of anti-DNA binding activity and anti-transformation activity from anti-CRd bodies with competent and non-competent Rd bacteria. Samples $(0.5 \mathrm{ml})$ of anti-CRd bodies (AB) were absorbed with $0.5 \mathrm{ml}$ of $1.5 \times 10^{10}$ viable centres $/ \mathrm{ml}$ of either competent $(\mathrm{C})$ or non-competent (NC) bacteria prior to assaying for c.p.m. of irreversibly bound ${ }^{14} \mathrm{C}$-labelled DNA and number of transformations to novobiocin resistance $\left(\mathrm{Nb}_{1}\right)$.

\section{Effects of heat and papain on anti-CRd bodies}

Anti-CRd bodies were tested for sensitivity to heat (Table 3). Heating the antibodies in a boiling water bath $\left(92^{\circ} \mathrm{C}\right)$ for 10 min reduced their capacity to inhibit transformation by $60 \%$. Heating the anti-CRd bodies at $56{ }^{\circ} \mathrm{C}$ for $30 \mathrm{~min}$ destroyed only $5 \%$ of their inhibitory capacity.

Both anti-CRd bodies and anti-NCRd bodies decreased the viable centre titre to one-third of the saline control value, possibly by agglutination of the bacteria rather than by bacteriolysis, since all the complement had been removed from the gamma-globulin preparation (Pfeiffer, 1894). This assumption was confirmed by treating the antisera with papain, which splits divalent antibodies to non-agglutinating monovalent forms which still bind to specific 
antigens (Porter, 1958). Table 4 shows the effect of pretreating anti-CRd bodies with papain prior to adding the antibodies to competent bacteria. Papain treatment removed the agglutinating effect of the antiserum but only destroyed $10 \%$ of the inhibitory activity of the anti-CRd bodies on transformation. In addition to these results, it was determined that anti-CRd bodies were refractory to extensive inactivation by trypsin.

\section{Antibody absorption with competent and non-competent bacteria}

Anti-CRd bodies were absorbed with competent and non-competent bacteria (Fig. 4). The experiment was done several times using different bacterial concentrations. Competent organisms were effective in absorbing out the inhibitor of both DNA binding and transformation. Non-competent bacteria failed to absorb the inhibitor of DNA binding from antiCRd bodies. However, non-competent bacteria did absorb the inhibitor of transformation found in anti-CRd bodies.

\section{DISCUSSION}

Competent bacteria were unique in stimulating the production of antibodies which inhibited DNA binding and transformation. Because the antibodies did not alter the biological activity of DNA, their effects must have been exerted on the organisms, specifically on the bacterial surface, since antibodies do not normally penetrate bacterial cells. It was concluded that the inhibiting component in rabbit antiserum was antibody, i.e. it was in the gamma globulin fraction, was heat-sensitive only at high temperatures (Table 3), and gave linear dose-response curves (Fig. I). Furthermore, the inhibitory component of the antiserum was produced only in response to competent organism injections (Table I). These experimental results showed that surface uptake sites for transforming DNA do exist on competent Haemophilus influenzae.

Transformations were reduced to $7 \%$ of the pre-immunization control and bound DNA to $21 \%$ (Table I). This threefold difference was thought to be due to a difference in sensitivity of the two assay procedures. Dose-response slopes (Fig. I) for inhibition of transformation and DNA binding confirmed that transformation is more sensitive to inhibition by anti-CRd bodies. A comparison of the slopes of the straight-line portions of these curves shows that twice as many antibody molecules are required to block irreversible attachment of DNA as are required to block transformation. Our findings offer substantial evidence that more than one bacterial component is involved in uptake of transforming DNA and that there is at least one step in addition to what has been referred to as the energy-requiring irreversible uptake step. In this case, transformation would depend on both processes being functional and would be inhibited when either one is blocked; thus, transformation would be expected to be more susceptible to antibody inhibition, as our results indicate, than irreversible DNA binding. Also, with antibodies against DNA-uptake sites, competent bacteria can be fractionated and the fractions assayed for adsorption of anti-DNA binding and anti-transformation antibodies (unpublished observations).

The idea of multiple steps being involved in DNA uptake is also supported by the experiment of Erickson, Young \& Brown (I969) using anti-DNA serum to block transformation of Bacillus subtilis. They found that irreversibly bound transforming DNA, which is refractory to the action of DNase, is still susceptible to anti-DNA serum inactivation. This is interpreted to mean that irreversibly bound DNA remains on the bacterial surface susceptible to anti-DNA antibodies before it is taken into the organism and integrated. The conclusion from their results and our experiments is that irreversible binding is only a part of the active uptake mechanism for transforming DNA. 
When anti-CRd bodies were absorbed with non-competent Rd bacteria, it was expected that little or no absorption of antibody against DNA binding or transformation would occur, since non-competent bacteria do not stimulate the production of either of these two groups of antibodies (Table I). Our results showed that very little absorption of anti-DNA binding antibody occurred (Fig. 4); however, nearly $50 \%$ of the anti-transformation activity was absorbed by non-competent bacteria (Fig. 4). This indicates one of two things: (i) noncompetent bacteria have part of the DNA uptake mechanism at all times; or (ii) the L-valine block used to inhibit the development of competence (Spencer \& Herriott, 1965) prevented only part of the DNA uptake mechanism from developing.

Haemophilus influenzae grown in the presence of inosine and lactate is potentially capable of becoming competent (Ranhand \& Herriott, 1966; Ranhand, 1969, I970; Miller \& Huang, I970). According to Ranhand's model (1969) for the role of inosine and lactate, inactive sites are formed during the growth phase for the uptake of DNA, and then the sites are modified to an active state by subsequent incubation in M II medium. If this model is correct, then bacteria blocked in their development of competence by L-valine during incubation in M II medium have part of the uptake mechanism in an inactive form. The effect of L-valine, the necessity of inosine and lactate for competence, and the absorption of anti-transformation antibody by non-competent bacteria indicate that the sites are at least partly present on non-competent organisms used for this research. The inactive uptake sites acted like complex haptens by absorbing antibody against part of the active uptake mechanism but were not themselves able to stimulate antibody production that would inhibit DNA binding or transformation.

A preliminary report of this work was given at the 1970 annual meeting of the American Society for Microbiology. D.P.B. was supported at the Los Alamos Scientific Laboratory by a predoctoral fellowship from the Associated Western Universities, Inc. The work was also performed under the auspices of the U.S. Atomic Energy Commission. Final writing of the manuscript was done at the Killgore Research Center in Canyon, Texas.

\section{REFERENCES}

Alexander, H. E. \& LeIdy, G. (1953). Induction of streptomycin resistance in sensitive $H$. influenzae by extracts containing DNA from resistant $H$. influenzae. Journal of Experimental Medicine 97, 17-3I.

Barnhart, B. J. \& Herriott, R. M. (1963). Penetration of DNA into Hemophilus influenzae. Biochimica et biophysica acta 76, 25-39.

Erickson, R. J., Young, F. E. \& Braun, W. (I969). Binding of rabbit gamma globulin by competent Bacillus subtilis cultures. Journal of Bacteriology 99, 125-131.

Fox, F. M. \& Нотснкіss, R. D. (1957). Initiation of bacterial transformation. Nature, London 179, 13221325.

Goodgal, S. H. \& Herriott, R. M. (1961). Studies on transformation of Haemophilus influenzae. I. Competence. Journal of General Physiology 44, I $20 \mathrm{I}-\mathrm{I} 227$.

Herriott, R. M., Meyer, E. Y., Vogt, M. \& Modan, M. (1970). Defined medium for growth of Haemophilus influenzae. Journal of Bacteriology ror, 513-516,

Keкwick, R. A. (1938). Observations on the crystallizable albumin fraction i of horse serum. Biochemical Journal 32, 552-562.

Miller, D. H. \& Huang, P. C. (1970). Time dependent effect of inosine on competence development in Haemophilus infuenzae. Journal of Bacteriology 104, 775-779.

Nova, G., Gallis, A. \& Beiser, S. M. (I963). Bacterial transformation: An antigen specific for 'competent' pneumococci. Nature, London I97, 903-904.

Pakula, R. (1965). Inhibition of transformation of streptococci by antibodies. Journal of Bacteriology 90 , I 501-I502. 
PffifFer, R. (I 894). Weitere Untersuchungen über das Wesen der Choleraimmunität über spezifisch baktericide Processe. Zeitschrift für Hygiene 18, I-16.

PORTER, R. R. (1958). Separation and isolation of fractions of rabbit gamma-globulin containing the antibody and antigenic combining sites. Nature, London 182, 670-67I.

RANHAND, J. M. \& HeRriotT, R. M. (1966). Inosine and lactate: Factors critical during growth for development of competence in Haemophilus influenzae. Biochemical and Biophysical Research Communications 22, 59I-596.

RANHAND, J. M. (1969). Competence in Haemophilus influenzae. A role for inosine and lactate in the primary cell-deoxyribonucleic acid attachment reaction. Journal of General Microbiology 57, 257-262.

Ranhand, J. M. (1970). Specificity of lactate for the development of competence in Haemophilus influenzae. Journal of General Microbiology 60, I4I-I44.

SNYDER, J. W. \& OTERo, R. B. (I970). Effect of specific antibodies on transformation of Neisseria catarrhalis $\left(\right.$ lys $\left.^{-}\right)$. Bacteriological Proceedings $\mathrm{G} \mathbf{2 1 7}, 48$.

SPENCER, R. T. \& HERRIOTT, R. M. (1965). Development of competence of Haemophilus influenzae. Journal of Bacteriology 90, 9I I-920.

Spizizen, J., Reilly, B. E. \& Evans, A. H. (1966). Microbial transformation and transfection. Annual Review of Microbiology 20, 37I-400.

StuY, J. H. (1962). Transformability of Haemophilus influenzae. Journal of General Microbiology 29, 537549.

StUY, J. H. \& STERN, D. (1964). The kinetics of DNA uptake by Haemophilus influenzae. Journal of General Microbiology 35, 39I-400.

TOMAZ, A. \& BeISER, S. M. (I965). Relationship between the competence antigen and the competence-activator substance in pneumococci. Journal of Bacteriology 90, I 226-1232. 